\title{
CADOMIAN PROTOLITH AGES OF EXOTIC MEGA BLOCKS FROM BUGAJ AND ANDRYCHÓW (WESTERN OUTER CARPATHIANS, POLAND) AND THEIR PALAEOGEOGRAPHIC SIGNIFICANCE
}

\author{
JOLANTA BURDA ${ }^{1}$, BEATA WOSKOWICZ-ŚLEZZAK ${ }^{1}$, URS KLÖTZLI ${ }^{2}$ and ALEKSANDRA GAWĘDA ${ }^{1}$ \\ ${ }^{1}$ Faculty of Earth Sciences, University of Silesia, Będzinska st. 60, 41-200 Sosnowiec, Poland \\ ${ }^{2}$ Department of Lithospheric Research, University of Vienna, Althanstrasse 14, 1090 Vienna, Austria
}

Received 9 April $2018 \quad$ Accepted 14 January 2019

\begin{abstract}
This study presents the first zircon U-Pb LA-MC-ICP-MS ages and whole-rock $\mathrm{Rb} / \mathrm{Sr}$ and $\mathrm{Sm} / \mathrm{Nd}$ data from exotic blocks (Bugaj and Andrychów) from the Western Outer Carpathians (WOC) flysch. The CL images of the zircon crystals from both samples reveal typical magmatic textures characterized by a well-defined concentric and oscillatory growth zoning. A concordia age $580.1 \pm 6.0 \mathrm{Ma}$ of the zircons from the Bugaj sample is considered to represent the crystallization age of this granite. The zircon crystals from the Andrychów orthogneiss yield an age of $542 \pm 21 \mathrm{Ma}$, interpreted as the uppermost Proterozoic, magmatic crystallization age of the granitoid protholith. The initial (at ca. $580 \mathrm{Ma}){ }^{87} \mathrm{Sr} /{ }^{86} \mathrm{Sr}$ ratios of the Bugaj granitoids (0.72997 and 0.72874) are highly radiogenic, pointing to the assimilation of an older, possibly strongly $\mathrm{Rb}$ enriched source to the Bugaj melt. The Nd isotope systematics $\left(\varepsilon_{\mathrm{Nd580}}-1.4\right.$ and 0.4$)$ also point to a significant contribution of such a distinct mantle source. On the basis of the sequence of magmatic events obtained from U-Pb zircon ages, we suggest that exotic mega blocks deposited to the WOC basins were related to the Brunovistulicum Terrane. They belong to the group of Vendian/Cambrian granitoids representing the latest, posttectonic expression of the Cadomian cycle.
\end{abstract}

Keywords: exotics, zircon U-Pb dating, Western Outer Carpathians, palaeogeography, Brunovistulicum.

\section{INTRODUCTION}

Despite the long period of research conducted in the Western Outer Carpathians (WOC) the genesis and tectonic evolution of their crystalline basement is still poorly recognized (e.g. Żelaźniewicz et al., 2009; Buła et al., 2015). At present the crystalline basement is hidden below thick Upper Jurassic-Neogene flysch deposits of the WOC proper (e.g. Książkiewicz, 1977; Oszczypko and Ślączka, 1985; Golonka et al., 2009). Fragments of crystalline rocks, so-called exotics (e.g. Burtanówna et al.,

Corresponding author: J. Burda e-mail: jolanta.burda@us.edu.pl
1937; Wieser, 1948), interpreted to be derived from uplifted ridges (cordilleras, Książkiewicz, 1953) and transported by turbidity currents and debris flows into the adjoining flysch basins, offer the opportunity to investigate the geotectonic history of these no longer existing provenance areas of the Carpathian flysch (e.g. Wieser, 1949, 1985; Książkiewicz, 1965; Oszczypko, 1975; Malik, 1978; Oszczypko et al., 2016).

A number of studies concerning the palaeogeography of the WOC have used a range of geochronological methods including K-Ar mica dating (Poprawa et al., 2004, 2005, 2006; Haber and Hałas, 2001), Th-U-total Pb monazite dating (Hanžl et al., 2000; Budzyń et al., 2008; Salata and Oszczypko, 2010; Oszczypko et al., 2016) and $\mathrm{U}-\mathrm{Pb}$ zircon geochronology (Michalik et al., 2006; Poprawa et al., 2006; Budzyń et al., 2011) to constrain 
the timing of magmatic and metamorphic processes recorded in the exotics. The general outcome of these investigations is that numerous exclusively pre-Alpine, in parts pre-Variscan ages were determined, but no obvious correlation of stratigraphic and tectonic position and/or geography emerged. From a methodological point of view this is due to the fact that especially $\mathrm{K}$-Ar mica ages are sensitive to thermal and metasomatic overprint thus obscuring any primary geochronological signal directly dating igneous or metamorphic events. This published radiometric age data set is therefore not conclusive for the unambiguous identification of protolith and metamorphic ages.

The main purpose of our study is to present and discuss zircon $\mathrm{U}-\mathrm{Pb}$ ages from two exotic mega blocks (a granite from Bugaj and an orthogneiss from Andrychów), representing the alimentary crystalline basement area of the WOC flysch. Due to the size of these two exotics $(>100 \mathrm{~m})$ it can safely be assumed that their loci of deposition is far more proximal to their respective shedding ridge(s) than the probably more distally derived pebbles dated in previous studies. Additionally, the latter might easily be re-sedimented making any palaeogeographic implications drawn from ages derived from such rocks severely ambiguous. The presented results provide new information to the ongoing discussion of the late Neoproterozoic palaeogeography of tectonic units which intervene between the East European Craton (Baltica) and the lithotectonic units of the Variscan orogeny (e.g. Belka et al., 2000; Nawrocki et al., 2004; Żelaźniewicz et al., 2009; Buła et al., 2015).

\section{GEOLOGICAL BACKGROUND}

The Western Carpathian Mountains are subdivided into the Inner Carpathians, consisting of pre-Alpine crystal- line basement units covered by Late Paleozoic to midCretaceous sediments (e.g. Oszczypko, 2004; Poprawa and Malata, 2006) and the Outer Carpathians, separated by the narrow, strongly tectonized Pieniny Klippen Belt (Fig. 1). The WOC are depicted as a complex nappe structure consisting of Upper Jurassic to Neogene flysch deposits, that were folded and thrusted onto the preAlpine European foreland during the upper Oligocene to the middle Miocene (e.g. Oszczypko, 1998, 2004; Oszczypko and Oszczypko-Clowes, 2003; Golonka et al., 2005; 2009; Oszczypko et al., 2006, Ślączka et al., 2006).

The crystalline basement constituting the pre-Alpine foreland (known only from boreholes) is divided into two basement blocks: the Upper Silesia Block (the northern part of the Brunovistulicum Terrane) to the West and the Małopolska Block to the East (Dudek, 1980; Buła, 2000; Finger et al., 2000; Żelaźniewicz et al., 2009; Buła et al., 2015). The Precambrian basement of the Upper Silesia Block is represented by a) Neoproterozoic (660-556 Ma) metamorphic and igneous rocks, b) Ediacaran anchimetamorphic flysch-type siliciclastics and c) Paleoproterozoic $(2.0 \mathrm{Ga})$ metamorphic rocks with Archean $(2.7 \mathrm{Ga})$ inheritance (Buła et al. 2015). The Neoproterozoic rocks of Małopolska Block are mainly represented by flyschtype series (Żelaźniewicz et al., 2009).

In the WOC several flysch basins were identified on the basis of lithostratigraphy (from south to north), i.e. the Magura, Silesian, Sub-Silesian and Skole basins (e.g. Bieda et al., 1963; Książkiewicz, 1972; Cieszkowski et al., 1985; Oszczypko, 2006). The basins were supplied with sediments from continental margins as well as from the inter-basinal elevations (ridges) separating subbasins (e.g., Książkiewicz, 1962, 1965; Unrug, 1963, 1968; Ślączka, 1986; Olszewska and Wieczorek, 2001; Poprawa et al., 2002, 2004; Golonka et al., 2008). Based

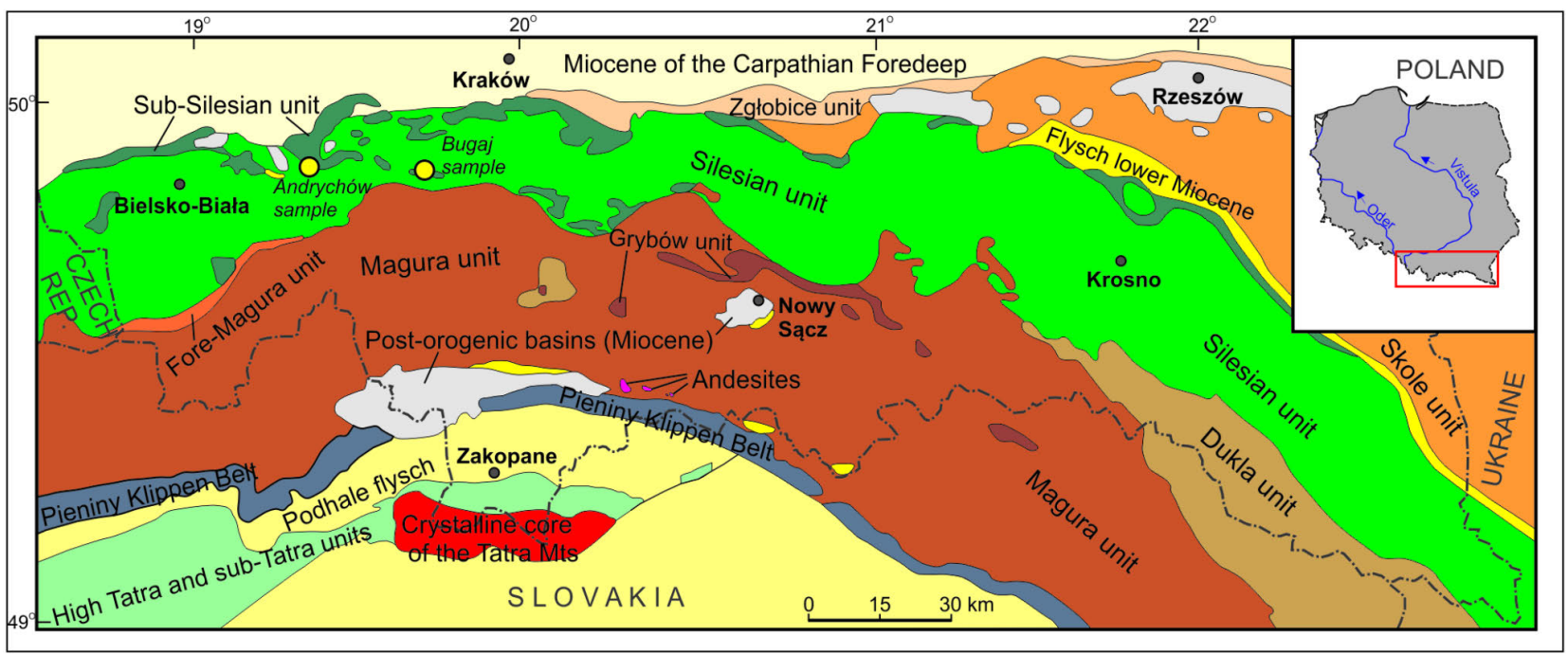

Fig. 1. Simplified geological map of the Polish part of the Western Carpathians (after Żelaźniewicz el al., 2011, modified) with the location of the investigated samples (shown as yellow dots). 
on studies of palaeotransport directions it was concluded that the Brunovistulicum and/or Małopolska Terranes (external to the WOC) and the inter-basinal Silesian Ridge were the most prominent source areas of the terrigenous material (e.g. Wieser, 1949, 1985; Książkiewicz, 1965; Sikora, 1976). The Silesian Ridge developed at the boundary between Variscan and Cadomian crustal blocks of the so-called North European platform (e.g. Golonka et al., 2005; Budzyń et al., 2011). The less prominent Andrychów Ridge, recognized in the Polish WOC emerged between the Silesian and Subsilesian-Skole basins (e.g. Książkiewicz, 1960, 1977; Golonka et al., 2005) to the NNE of the Silesian Ridge. This unit is represented by several huge $(>100 \mathrm{~m})$ exotic blocks, containing granitegneiss or mylonitized rocks of unknown age and Jurassic, Cretaceous and Paleogene limestones (Olszewska and Wieczorek, 2001; Ślączka et al., 2006).

\section{SAMPLING AND ANALYTICAL TECHNIQUES}

Three samples of crystalline rocks (Bu1, Bu2 and $\mathrm{An}$ ) from exotic mega blocks (Bugaj and Andrychów) were investigated. These blocks, located on the boundary between the Silesian and Subsilesian units, are interpreted as olistoliths of the Silesian nappe (Ślączka and Kaminski, 1998; Golonka et al., 2005; Cieszkowski et al., 2009, 2012). The samples $\mathrm{Bu} 1$ and $\mathrm{Bu} 2$ were collected in the western flow of the Cedron stream in Bugaj near Kalwaria Zebrzydowska (coordinates: 49 $50^{\prime} 56.40^{\prime \prime} \mathrm{N}$ $19^{\circ} 40^{\prime} 40.70^{\prime \prime E}$; Fig. 1). The sample An, representative for the metamorphic basement rocks of the Andrychów Ridge was collected from Pańska Góra Hill, SE of Andrychów (coordinates: 49॰51'10.17'N 19²1'28.95”E, Fig. 1). The two samples Bul and An, weighting about $25 \mathrm{~kg}$ each, were selected for $\mathrm{U}-\mathrm{Pb}$ dating.

\section{Whole-rock and mineral analysis}

Whole-rock samples were analysed by X-ray fluorescence (XRF) for major and large ion lithophile trace Elements (LILE) and by fusion and ICP-MS for high field strength elements (HFSE) and rare earth elements (REE) in the Bureau Veritas Minerals (Canada). Preparation involved lithium borate fusion and dilute digestions for XRF and lithium borate decomposition or aqua regia digestion for ICP-MS. LOI was determined at $1000^{\circ} \mathrm{C}$. REE were normalized to $\mathrm{C} 1$ chondrite (Sun and McDonough, 1989).

Microprobe analyses of rock-forming and accessory minerals were undertaken in the Inter-Institutional Laboratory of Microanalyses of Minerals and Synthetic Substances, Warsaw, using a Cameca SX 100 electron microprobe operating in the wavelength-dispersive spectroscopic (WDS) mode with the following conditions: $15 \mathrm{kV}$ accelerating voltage, $20 \mathrm{nA}$ beam current, $1-5 \mu \mathrm{m}$ beam diameter, peak count-time of $20 \mathrm{~s}$ and background counttime of $10 \mathrm{~s}$.

\section{$\mathrm{Rb}-\mathrm{Sr}$ and $\mathrm{Sm}-\mathrm{Nd}$ whole rock isotope analysis}

$\mathrm{The} \mathrm{Rb}-\mathrm{Sr}$ and $\mathrm{Sm}-\mathrm{Nd}$ analytical work was performed at the Laboratory of Geochronology, Department of Lithospheric Research, University of Vienna. $\mathrm{Rb}, \mathrm{Sr}, \mathrm{Sm}$ and $\mathrm{Nd}$ concentrations were determined from two different sample aliquots by isotope dilution (ID) using ${ }^{87} \mathrm{Rb}-{ }^{84} \mathrm{Sr}$ and ${ }^{147} \mathrm{Sm}^{150} \mathrm{Nd}$ spikes. Rb, Sm and Nd ID samples were measured as metals from a $\mathrm{Re}$ (single: $\mathrm{Rb}$; double: $\mathrm{Nd}$ and Sm) filament using a Finnigan ${ }^{\mathrm{TM}}$ MAT262 mass spectrometer, while Sr ID and isotope composition (IC) and Nd IC samples were run on a ThermoFinnigan ${ }^{\mathrm{TM}}$ Triton TI TIMS machine. Maximum total procedural blanks were $<1 \mathrm{ng}$ for $\mathrm{Sr}$ and $50 \mathrm{pg}$ for $\mathrm{Nd}$ and were taken as negligible. Within-run mass fractionation for $\mathrm{Nd}$ and $\mathrm{Sr}$ isotope compositions (IC) was corrected to ${ }^{146} \mathrm{Nd} /{ }^{144} \mathrm{Nd}=0.7219$, and ${ }^{86} \mathrm{Sr} /{ }^{88} \mathrm{Sr}=0.1194$, respectively. Uncertainties on the $\mathrm{Nd}$ and $\mathrm{Sr}$ isotope ratios are quoted typical as $2 \sigma_{\mathrm{m}}$. Errors for the ${ }^{87} \mathrm{Rb} /{ }^{86} \mathrm{Sr}$ and ${ }^{147} \mathrm{Sm} /{ }^{144} \mathrm{Nd}$ ratios, respectively, are taken as $\pm 1 \%$, or smaller, based on iterative sample analysis and spike recalibration. During the period of investigation a ${ }^{143} \mathrm{Nd} /{ }^{144} \mathrm{Nd}$ ratio of $0.511850 \pm 0.000005(\mathrm{n}=5)$ and a ${ }^{87} \mathrm{Sr}{ }^{86} \mathrm{Sr}$ ratio of $0.710274 \pm 0.000008(\mathrm{n}=5)$ were determined for the La Jolla (Nd) and the NBS987 (Sr) international standards, respectively. Details of techniques, accuracy and data precision of $\mathrm{Rb}-\mathrm{Sr}$ and $\mathrm{Sm}-\mathrm{Nd}$ isotopic measurements are given by Thöni et al. (2008).

\section{Zircon separation, $\mathrm{CL}$ imaging and $\mathrm{U}-\mathrm{Th}-\mathrm{Pb} \mathrm{MC}-$ ICP-MS dating}

Zircon crystals were separated using standard techniques (crushing, hydrofracturing, washing, Wilfley table, magnetic separator and handpicking). The separation was carried out in the Institute of Geological Sciences, Polish Academy of Sciences, Cracow. Zircon grains were selected for the morphological study using scanning electron microscopy and then imaged by cathodoluminescence using a FET Philips 30 electron microscope $(15 \mathrm{kV}$ and $1 \mathrm{nA}$ ) at the Faculty of Earth Sciences, University of Silesia, Sosnowiec, Poland.

The LA-MC-ICP-MS (Laser Ablation Multi Collector ICP-MS) analytical work was performed in two sessions at the joint ICP-MS laboratory of the Department of Earth Sciences, Karl-Franzens-University Graz and the Institute of Applied Geosciences, Graz Technical University. Analytical procedures followed the methodology outlined in Klötzli et al. (2009). Zircon ${ }^{206} \mathrm{~Pb} /{ }^{238} \mathrm{U},{ }^{207} \mathrm{~Pb} /{ }^{206} \mathrm{~Pb}$, and ${ }^{208} \mathrm{~Pb} /{ }^{232} \mathrm{Th}$ ratios and ages were determined using a $193 \mathrm{~nm}$ Ar-F excimer laser (NewWave) coupled to a multi-collector ICP-MS (Nu Instruments Plasma II). Ablation using $\mathrm{He}$ as carrier gas was raster-wise according to the CL zonation pattern of the zircons. Line widths for rastering were $10-15 \mu \mathrm{m}$ with a rastering speed of $5 \mu \mathrm{m} / \mathrm{sec}$. Energy densities were $5-5.5 \mathrm{~J} / \mathrm{cm}^{2}$ with a repetition rate of $10 \mathrm{~Hz}$. The He carrier gas $(0.7 \mathrm{l} / \mathrm{min})$ was mixed with the Ar carrier gas flow prior to the ICP plasma torch. 
Ablation duration was 30 to $70 \mathrm{sec}$ with a $30 \mathrm{sec}$ gas and $\mathrm{Hg}$ blank measurement preceding ablation. Ablation count rates were corrected accordingly using the mean blank measurement intensities of the individual masses. Remaining counts on mass 204 were interpreted as representing ${ }^{204} \mathrm{~Pb}$. Static mass spectrometer analysis was as follows: ${ }^{238} \mathrm{U}$ and ${ }^{232} \mathrm{Th}$ were measured in Faraday detectors, ${ }^{208} \mathrm{~Pb},{ }^{207} \mathrm{~Pb},{ }^{206} \mathrm{~Pb},{ }^{204} \mathrm{~Pb}+{ }^{204} \mathrm{Hg}$ and ${ }^{202} \mathrm{Hg}$ in discrete ion counter detectors. An integration time of $1 \mathrm{sec}$ was used for all measurements. The ion counter - Faraday and inter-ion counter gain factors were determined before the analytical session using the reference zircon Plešovice (Sláma et al., 2008). The overall sensitivity for ${ }^{206} \mathrm{~Pb}$ on reference zircon Plešovice was $c .0 .18 \mathrm{mV} /$ weight-ppm ${ }^{206} \mathrm{~Pb}$. For ${ }^{238} \mathrm{U}$ the corresponding value was $c$. $0.39 \mathrm{mV} /$ weight-ppm U. Isotopic ratios were calculated using the MS Excel spreadsheet LamTool U-Th-Pb version VI (Košler et al., 2008; Košler and Klötzli, unpublished). In order to avoid potential surface contamination, the signals from the first laser pass was rejected and untypical $\mathrm{Pb}$-peaks, from $\mathrm{Pb}$-rich inclusions, were removed in the LamTool spreadsheet. Mass and elemental bias and mass spectrometer drift of $\mathrm{U} / \mathrm{Pb}, \mathrm{Th} / \mathrm{Pb}$ and $\mathrm{Pb} / \mathrm{Pb}$ ratios, respectively, were corrected applying the "intercept method" of Sylvester and Ghaderi (1997). The calculated ${ }^{206} \mathrm{~Pb} /{ }^{238} \mathrm{U}$ and ${ }^{207} \mathrm{~Pb} /{ }^{206} \mathrm{~Pb}$ intercept values, respectively, were corrected for mass discrimination from analyses of reference zircon Plešovice zircon (Sláma et al., 2008) measured during the analytical session using a standard bracketing method (Klötzli et al., 2009). The correction utilizes regression of standard measurements by a quadratic function. No common $\mathrm{Pb}$ correction was applied to the data. Final age calculations were performed with Isoplot(C) 3.75 (Ludwig, 2012). Reference zircon Plešovice (Sláma et al., 2008) was also used as secondary standard in order to derive an estimate of the overall uncertainties associated with the age determinations. 4 and 7 measurements where additionally made during the two analytical session, which resulted in concordia ages of $337.2 \pm 3.6 \mathrm{Ma}$ and $337 \pm 10 \mathrm{Ma}$, respectively. These are within error identical to the accepted reference ${ }^{206} \mathrm{~Pb} /{ }^{238} \mathrm{U}$ age of $337.13 \pm 0.37 \mathrm{Ma}$ (Sláma et al., 2008). These uncertainties where propagated in quadrature to the single dates in order to account for the overall analytical dispersion of the LA method (Klötzli et al., 2009). All errors reported for LA data are at the 2-sigma level.

\section{PETROGRAPHY AND WHOLE-ROCK GEO- CHEMISTRY}

\section{Bugaj granite mega block}

The samples collected from the Bugaj mega block are coarse-grained granite (Bul, Fig. 2a, Fig. 3) to granodiorite (Bu2, Fig. 3), lacking any visible orientation, locally porphyritic. They are composed of pinkish K-feldspars $\left(\mathrm{Or}_{91-93} \mathrm{Ab}_{5-6} \mathrm{Cn}_{1-2}\right)$, weakly zoned oligoclase $\left(\mathrm{An}_{18-25}\right)$, biotite showing a brown-yellow pleochroism $(\mathrm{Ti}=0.38$ 0.42 a.p.f.u.; $\# f m=0.65-0.66$ ), locally replaced by chlorite and associated with secondary rutile. Accessory minerals are $(\mathrm{Ca}, \mathrm{F})$-apatite and zircon. Sporadically rounded monzonitic enclaves up to $5-10 \mathrm{~cm}$ in size can be found, showing a sharp contact with the surrounding host rock. The enclaves are composed of fine-grained biotite $(\mathrm{Ti}=$ $0.30-0.38$ a.p.f.u. $)$, oligoclase $\left(\mathrm{An}_{20-26}\right)$, and quartz. Accessory (Ca, F)-apatite is also observed (BuC, Fig. 3).

Studied rocks are peraluminous (ASI $=1.16-1.23$ ) with silica contents around $60-71$ wt. $\%, \mathrm{~K}_{2} \mathrm{O} \geq \mathrm{Na}_{2} \mathrm{O}$ and $\mathrm{Rb} / \mathrm{Sr}$ ratios $=1.1-1.4$ (Table 1 ). The rocks belong to the high K-calc-alkaline series and are intermediate between the ferroan and magnesian families of the Frost and Frost (2008) geochemical classification. Chondrite-normalized (Sun and McDonough, 1989) REE patterns show low LREE enrichment $\left(\mathrm{Ce}_{\mathrm{N}} / \mathrm{Yb}_{\mathrm{N}}=3.18-6.34\right)$ and a strong negative Eu anomaly $\left(\mathrm{Eu} / \mathrm{Eu}^{*}=0.38-0.57\right.$; Table 1; Fig. 3b). Magma crystallization temperatures calculated on the basis of the Zr-saturation geothermometer of Watson and Harrison (1983) are in the range of $800-850^{\circ} \mathrm{C}$

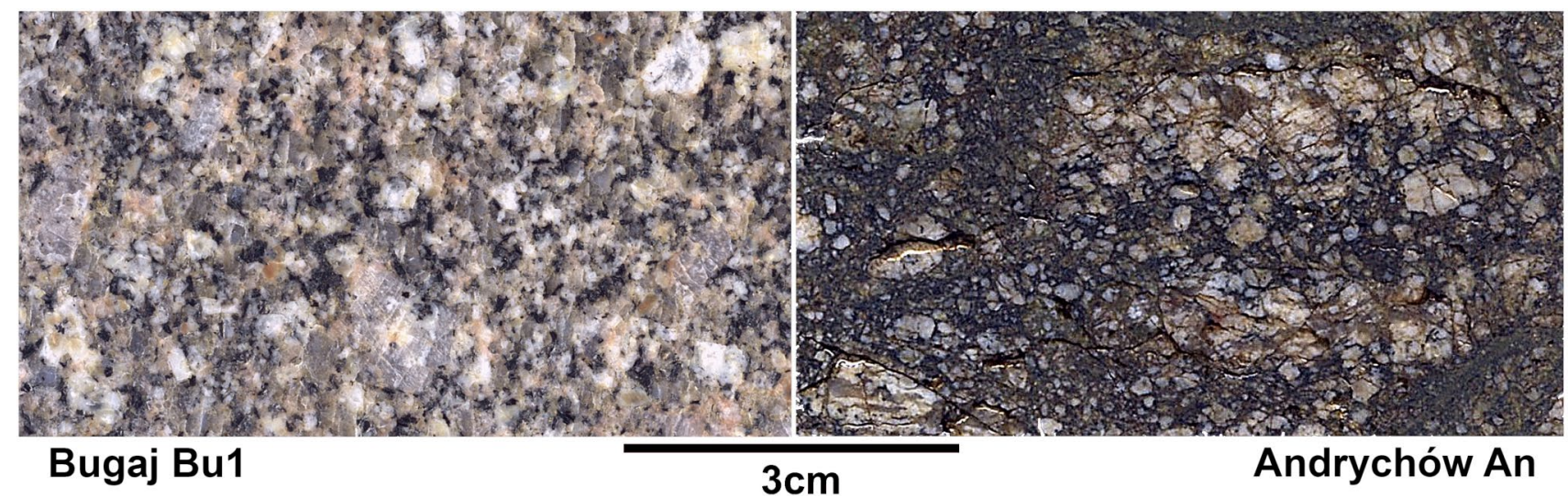

Fig. 2. Field photo (a) of the Bugaj granitoid (sample Bu1) and field photo (b) of the Andrychów orthogneiss (sample An). 

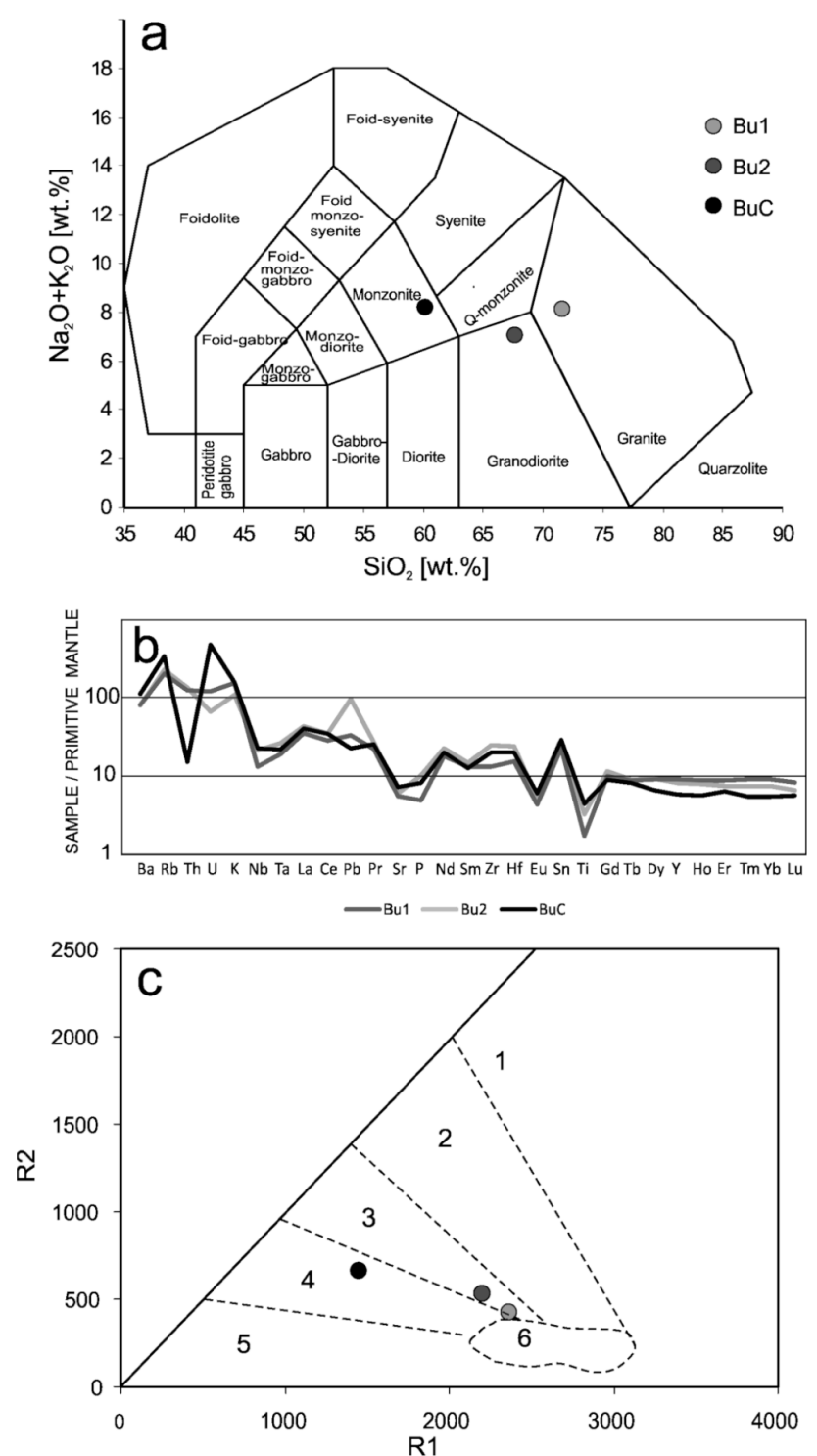

Fig. 3. Classification position of the Bugaj granitoids in: (a) alkali $\left(\mathrm{K}_{2} \mathrm{O}\right.$ $+\mathrm{Na}_{2} \mathrm{O}$ ) versus $\mathrm{SiO}_{2}$ (TAS) classification diagram (Middlemost, 1985); (b) Primitive mantle-normalized (Sun and McDonough, 1989) multielement "spider" diagrams; (c) classification position of the Bugaj granitoids in Multicationic R1-R2 diagram (De La Roche et al.,1980), with fields numbered according to Batchelor and Bowden (1985); 1 - mantle fractionates, 2 - pre-plate collision suites, 3 - post-collision suites, 4 - late orogenic magmas, 5 - anorogenic suites, 6 - syncollisional (anatectic) suites. $R 1=4 \mathrm{Si}-11(\mathrm{Na}+\mathrm{K})-2(\mathrm{Fe}+\mathrm{Ti}) ; \mathrm{R} 2=6 \mathrm{Ca}$ $+2 \mathrm{Mg}+\mathrm{Al}$

(Table 1). The primitive-mantle-normalized multielement diagram points to an arc-setting of the magma, with typical $\mathrm{Nb}$ and $\mathrm{Ta}$ negative anomalies, whereas the Batchelor and Bowden (1985) classification suggests a post-collisional to late-orogenic magmatic suite (Fig. 3b, 3c). Granodiorite-granite rocks show relatively high
Table 1. Chemical composition and selected petrological indicators of Bugaj granitoid rocks.

\begin{tabular}{|c|c|c|c|}
\hline Sample No. & Bu1 & Bu2 & $\mathrm{BuC}$ \\
\hline $\mathrm{SiO}_{2}$ & 71.56 & 67.58 & 60.03 \\
\hline $\mathrm{TiO}_{2}$ & 0.38 & 0.7 & 0.98 \\
\hline $\mathrm{Al}_{2} \mathrm{O}_{3}$ & 14.13 & 14.89 & 16.63 \\
\hline $\mathrm{Fe}_{2} \mathrm{O}_{3 \mathrm{~T}}$ & 3.04 & 5.31 & 8.32 \\
\hline $\mathrm{MnO}$ & 0.06 & 0.09 & 0.14 \\
\hline $\mathrm{MgO}$ & 0.77 & 1.34 & 2.46 \\
\hline $\mathrm{CaO}$ & 0.92 & 1.5 & 1.89 \\
\hline $\mathrm{Na}_{2} \mathrm{O}$ & 3.36 & 3.83 & 3.33 \\
\hline $\mathrm{K}_{2} \mathrm{O}$ & 4.79 & 3.36 & 4.86 \\
\hline $\mathrm{P}_{2} \mathrm{O}_{5}$ & 0.11 & 0.22 & 0.18 \\
\hline LOI & 0.71 & 1.13 & 0.9 \\
\hline Total & 99.83 & 99.95 & 99.72 \\
\hline $\mathrm{Sr}$ & 121.2 & 128 & 152.3 \\
\hline $\mathrm{Ba}$ & 578 & 562 & 793 \\
\hline $\mathrm{Rb}$ & 135.6 & 146.9 & 219.3 \\
\hline Cs & 8.3 & 10.3 & 13.1 \\
\hline Th & 11 & 11.7 & 1.3 \\
\hline $\mathrm{U}$ & 2.6 & 1.4 & 10.1 \\
\hline $\mathrm{Ga}$ & 16 & 20.4 & 20.5 \\
\hline $\mathrm{Cr}$ & 82 & 109.5 & 116.3 \\
\hline$\overline{\mathrm{Ni}}$ & 11 & 14 & 27.9 \\
\hline $\bar{V}$ & 43 & 75 & 135 \\
\hline $\mathrm{Zr}$ & 150.9 & 283.6 & 226.8 \\
\hline $\mathrm{Hf}$ & 4.9 & 7.6 & 6.2 \\
\hline $\bar{Y}$ & 42.9 & 37.9 & 27 \\
\hline$\overline{\mathrm{Nb}}$ & 9.8 & 15.4 & 16.1 \\
\hline $\mathrm{Ta}$ & 0.8 & 1.1 & 0.9 \\
\hline $\mathrm{La}$ & 24.6 & 30.3 & 27.9 \\
\hline $\mathrm{Ce}$ & 52.6 & 62.4 & 61.9 \\
\hline $\mathrm{Pr}$ & 6.35 & 7.56 & 7.06 \\
\hline$\overline{\mathrm{Nd}}$ & 24.7 & 30.6 & 27.3 \\
\hline Sm & 5.96 & 6.63 & 5.64 \\
\hline $\mathrm{Eu}$ & 0.75 & 0.87 & 1.01 \\
\hline$\overline{\mathrm{Gd}}$ & 6.04 & 6.9 & 5.45 \\
\hline $\mathrm{Tb}$ & 0.99 & 0.99 & 0.89 \\
\hline Dy & 6.96 & 6.97 & 4.9 \\
\hline $\mathrm{Ho}$ & 1.49 & 1.3 & 0.95 \\
\hline $\mathrm{Er}$ & 4.32 & 3.62 & 3.1 \\
\hline $\mathrm{Tm}$ & 0.69 & 0.56 & 0.41 \\
\hline$\overline{Y b}$ & 4.56 & 3.67 & 2.69 \\
\hline Lu & 0.64 & 0.5 & 0.42 \\
\hline$\overline{\mathrm{ASI}}$ & 1.17 & 1.23 & 1.21 \\
\hline$\# \mathrm{mg}$ & 0.56 & 0.7 & 0.31 \\
\hline $\mathrm{Rb} / \mathrm{Sr}$ & 1.12 & 1.15 & 1.44 \\
\hline $\begin{array}{l}\text { REE } \\
\end{array}$ & 140.65 & 162.87 & 149.62 \\
\hline Eu/Eu* & 0.8 & 0.39 & 0.56 \\
\hline $\mathrm{CeN}_{\mathrm{N}} / \mathrm{Yb}_{\mathrm{N}}$ & 3.18 & 4.68 & 6.34 \\
\hline $\mathrm{Th}_{\mathrm{N}} / \mathrm{U}_{\mathrm{N}}$ & 1.04 & 2.06 & 0.03 \\
\hline $\mathrm{Tzr}\left[{ }^{\circ} \mathrm{C}\right]$ & 798 & 850 & 818 \\
\hline
\end{tabular}

Explanations:

LOD - limits of detection; $L O I$ - loss of ignition; $E u / E u^{*}=E u / \sqrt{\mathrm{Sm}} \cdot \mathrm{Gd}$; $A S I=\mathrm{Al}_{2} \mathrm{O}_{3} /\left(\mathrm{CaO}+\mathrm{Na}_{2} \mathrm{O}+\mathrm{K}_{2} \mathrm{O}-3.33 \mathrm{P}_{2} \mathrm{O}_{5}\right)$ (in molecular values); $T_{z r}=$ temperature calculated according to Watson and Harrison (1983) procedure. 
$\mathrm{Th}_{\mathrm{N}} / \mathrm{U}_{\mathrm{N}}$ ratios (2.06 and 1.05 respectively), whereas the monzonitic enclave shows a strong positive $U$ anomaly and a $T h_{N} / U_{N}$ ratio of 0.03 , suggesting a highly oxidised source (possibly mantle-type?) of the monzonitic magma (Fig. 3b; Table 1).

The whole-rock isotope geochemistry data of two Bugaj mega block samples are presented in Table 2. Both samples $(B u 1, B u 2)$ show nearly identical ${ }^{87} \mathrm{Rb} /{ }^{86} \mathrm{Sr}$ ratios (3.154 \pm 0.032 and $3.236 \pm 0.032)$ as well as ${ }^{87} \mathrm{Sr} /{ }^{86} \mathrm{Sr}$ ratios $(0.756053 \pm 0.000004$ and $0.755499 \pm 0.000004)$. The initial ${ }^{87} \mathrm{Sr} /{ }^{86} \mathrm{Sr}_{(580 \mathrm{Ma})}$ ratios are 0.72997 and 0.72874 .

Contrary to the above the Sm-Nd isotope systematics of the two Bugaj mega block samples are dissimilar: ${ }^{147} \mathrm{Sm} /{ }^{144} \mathrm{Nd}$ ratios are $0.1521 \pm 0.0015$ (Bu1) and $0.1366 \pm 0.0014 \quad(\mathrm{Bu} 2)$. The ${ }^{143} \mathrm{Nd} /{ }^{144} \mathrm{Nd}$ ratios are $0.512397 \pm 0.000004$ and $0.512428 \pm 0.000005$, respectively. The resulting $\varepsilon_{\mathrm{Nd} 580}$ are -1.4 and 0.4 .

\section{Andrychów orthogneiss mega block}

The sample $(A n)$ is a medium-grained augen gneiss (Fig. 2b), consisting of quartz, K-feldspar, plagioclase $\left(\mathrm{An}_{10-18}\right)$ and biotite. The foliation is defined by biotite, quartz ribbons and elongate feldspars. Accessory minerals are apatite and zircon. Due to the penetrative lowtemperature and structural overprinting of the Andrychów mega block rocks, no detailed micro-chemical analyses, whole rock chemistry as well as $\mathrm{Rb}-\mathrm{Sr}$ and $\mathrm{Sm}-\mathrm{Nd}$ isotope whole rock geochemistry were obtained.

\section{ZIRCON CHARACTERISTICS AND U-PB AGES}

\section{Bugaj mega block}

The zircons are colourless or slightly pink, euhedral, normal to very long-prismatic, even to acicular (aspect ratios $1: 1$ to $1: 10$ ). Grain sizes vary in length from ca. 50 to $350 \mu \mathrm{m}$ (Fig. 4). A small percentage of zircon grains show an unusual habit contrasting markedly with the prismatic and acicular crystals (Fig. 4, p6Bu81). This habit is tabular, strongly flattened on the [110] crystal face (elongation ratio $<1$ ). The typology falls into the $\mathrm{S} 4$ subtype group of Pupin (1980).

The cathodoluminescence (CL) images reveal a complexity of the internal structure. A significant number of crystals shows igneous oscillatory growth zoning, with growth bands varying between fine and broad within individual grains (Fig. 5). Luminescence is variable, but mostly moderate. Some grains display a blurred, light grey zonation, present in the centre of the zircon crystals (Fig. 5, p3Bu01). A small number of inherited cores were observed in normal-prismatic crystals (Fig. 5).

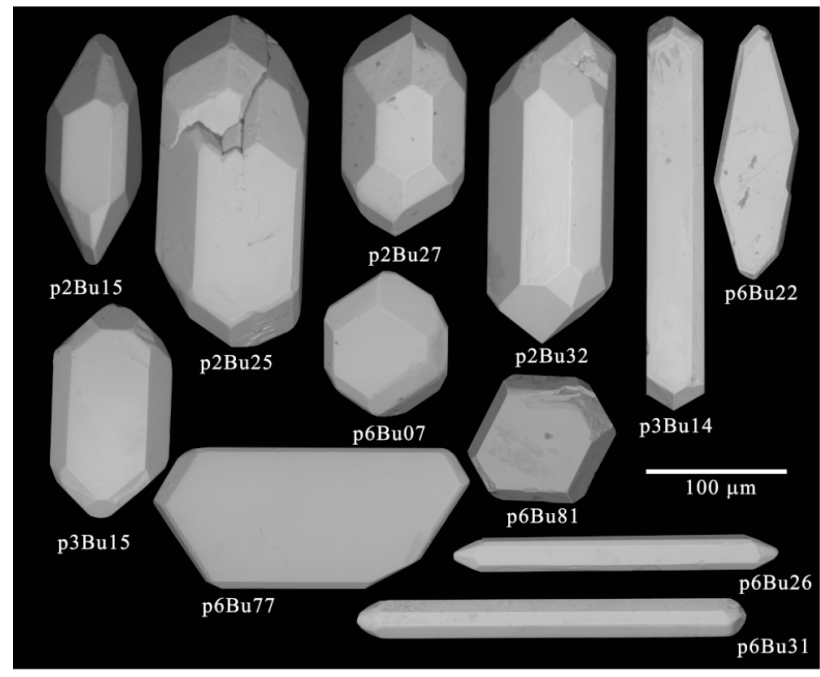

Fig. 4. Secondary electron (SE) images of selected zircon crystals from granite sample Bu1. See text for description.

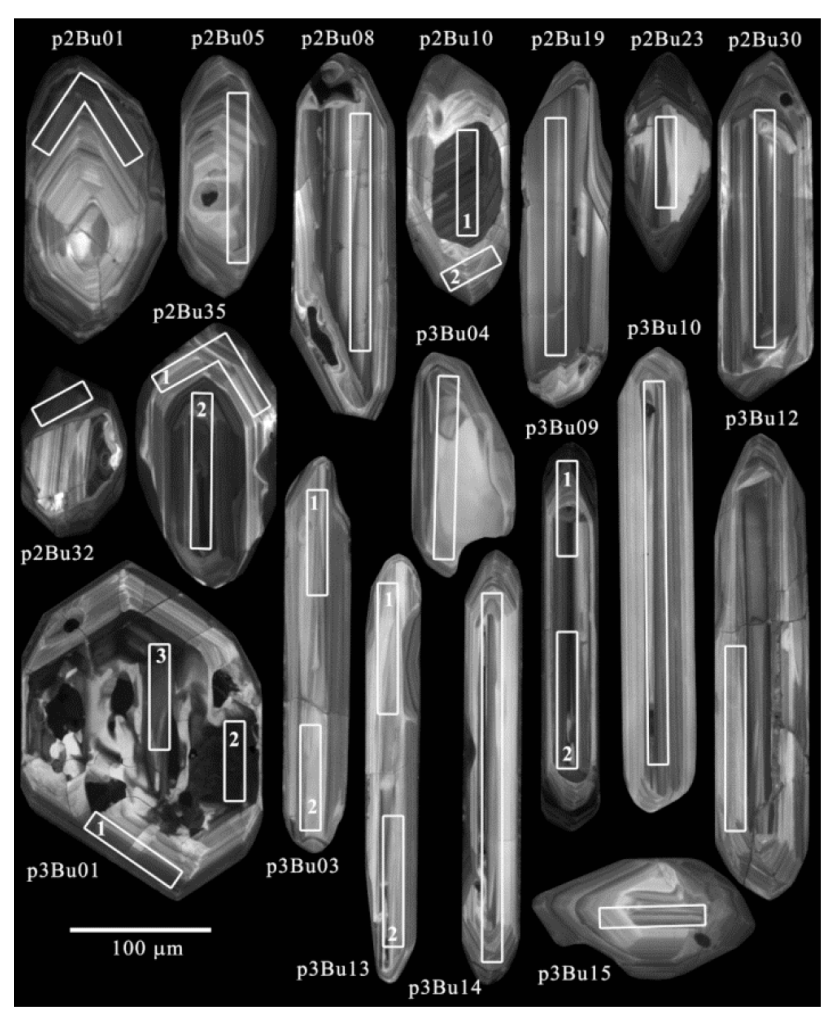

Fig. 5. Compiled cathodoluminescence (CL) images showing the range of textures observed in zircon crystals from granite sample Bu1. See text for details. The white rectangles show the approximate location of laser ablation trenches (confirmed by re-inspecting grains under $C L$ after the $L A$ analysis) and are not to scale. The numbers refer to the analytical data presented in Table 3.

Table 2. Rb-Sr and Sm-Nd whole rock isotope analysis of Bugaj granitoid rocks.

\begin{tabular}{|c|c|c|c|c|c|c|c|c|c|c|c|}
\hline $\begin{array}{l}\text { Isotope data } \\
\text { Bugaj1 }\end{array}$ & $\begin{array}{c}{ }^{87} \mathrm{Rb} / \mathbf{p l}^{6} \mathrm{Sr} \\
3.154\end{array}$ & $\begin{array}{l}\mathbf{\pm 2 s m} \\
0.032\end{array}$ & $\begin{array}{l}87 \mathbf{S r} / 86 \mathbf{S r} \\
0.756053\end{array}$ & $\begin{array}{c} \pm 2 \mathrm{sm} \\
0.000004\end{array}$ & $\begin{array}{c}{ }^{147} \mathrm{Sm} /{ }^{144} \mathrm{Nd} \\
0.1521\end{array}$ & $\begin{array}{c}\mathbf{\pm 2 s \mathrm { sm }} \\
0.0015\end{array}$ & $\begin{array}{c}143 \mathrm{Nd} /{ }^{144} \mathrm{Nd} \\
0.512397\end{array}$ & $\begin{array}{c}\mathbf{\pm 2 s m} \\
0.000004\end{array}$ & $\begin{array}{c}\mathrm{Sr}(580 \mathrm{Ma}) \\
0.729966\end{array}$ & $\begin{array}{c}\mathrm{Nd}(580 \mathrm{Ma}) \\
0.511819\end{array}$ & $\begin{array}{c}\mathrm{Nd} \text { (CHUR) } \\
-1.4\end{array}$ \\
\hline Bugaj2 & 3.236 & 0.032 & 0.755499 & 0.000004 & 0.1366 & 0.0014 & 0.512428 & 0.000005 & 0.728739 & 0.511909 & 0.4 \\
\hline
\end{tabular}


Crystal domains targeted for dating are characterized by the presence of a well-developed fine-scale oscillatory growth zonation (Fig. 5). 25 dates on 19 crystals were gained (Table 3, Fig. 5). Individual ${ }^{206} \mathrm{~Pb} /{ }^{238} \mathrm{U}$ dates range from $1751 \pm 78 \mathrm{Ma}$ to $431 \pm 19 \mathrm{Ma}$, whereas ${ }^{207} \mathrm{~Pb} /{ }^{206} \mathrm{~Pb}$ dates range from $1773 \pm 25 \mathrm{Ma}$ to $510 \pm 9$ $\mathrm{Ma}$, respectively. No systematic difference between the two populations could be detected. Thus the final age calculation took into account all analysed crystals of the Bugaj1 sample. One analysis (Bugaj1_p2bu_023A) is concordant at an age of ca. $1760 \mathrm{Ma}$ (Fig. 6a). 14 dates form a sub-concordant (discordance $<5 \%$ ) cluster with a lower intercept date of $580.1 \pm 6.0 \mathrm{Ma}$ (Fig. $6 \mathbf{b}$, model 1 solution, anchored at ${ }^{207} \mathrm{~Pb} /{ }^{206} \mathrm{~Pb}=0.85 \pm 0.05$, MSWD $=1.8$, Probability of fit $=0.031$ ). These crystals show a mean $\mathrm{Th} / \mathrm{U}$ of $0.16 \pm 0.07$. Three sub-concordant analyses (discordance $<5 \%$ ), characterized by comparably high $\mathrm{Th} / \mathrm{U}(0.30 \pm 0.04)$, form a cluster with a lower intercept date of $662 \pm 37 \mathrm{Ma}$ (not shown, model 1 solution, anchored at ${ }^{207} \mathrm{~Pb} /{ }^{206} \mathrm{~Pb}=0.85 \pm 0.05$, MSWD $=0.12$, Probability of fit $=0.89$ ). This lower intercept date is statistically distinguishable from the former one, also based on the disparate $\mathrm{Th} / \mathrm{U}$ ratios of the two clusters. The remaining 7 analyses are highly discordant with high $\mathrm{Th} / \mathrm{U}$ ratios $(0.72 \pm 0.35)$, again statistically distinguishable from the former two clusters.

\section{Andrychów mega block}

Zircon grains are euhedral, up to $300 \mu \mathrm{m}$ long, with aspect ratios from 1:1 to 1:3 (Fig. 7). They are clear, yellow and greenish yellow in colour.

In CL images a variably developed oscillatory growth zoning is the prominent feature of all analysed grains, as shown by moderate to weak luminescence. Some crystals display core-rim structures. The cores are characterized by oscillatory growth zoning with high/moderate CL intensity (Fig. 8).

Crystal domains targeted for dating are characterized by the presence of a well-developed fine-scale oscillatory growth zonation (Fig. 8). 15 dates on 10 crystals were gained (Table 3, Fig. 8). Individual ${ }^{206} \mathrm{~Pb} /{ }^{238} \mathrm{U}$ dates range from $2149 \pm 284 \mathrm{Ma}$ to $319 \pm 73 \mathrm{Ma}$, whereas ${ }^{207} \mathrm{~Pb} /{ }^{206} \mathrm{~Pb}$ dates range from $2324 \pm 295 \mathrm{Ma}$ to $554 \pm 29 \mathrm{Ma}$, respectively. One analysis (Andrychów_p3an_06A) is concordant at an age of $2123 \pm 23 \mathrm{Ma}$ (Fig. 9a). 7 dates form a sub-concordant (discordance $<5 \%$ ) cluster with a mean $\mathrm{Th} / \mathrm{U}$ of $0.23 \pm 0.11$. Two lower intercept dates can be calculated: i) $549 \pm 29 \mathrm{Ma}$ with an upper intercept at $2432 \pm 1500 \mathrm{Ma}$ (not shown, model 1 solution, MSWD $=0.99$, Probability of fit $=0.42$ ); ii) $542 \pm 21 \mathrm{Ma}$ with the upper intercept fixed at $2123 \pm 23 \mathrm{Ma}$ of analysis Andrychów_p3an_06A (Fig. 9b, model 1 solution, MSWD $=0.86$, Probability of fit $=0.53$ ).

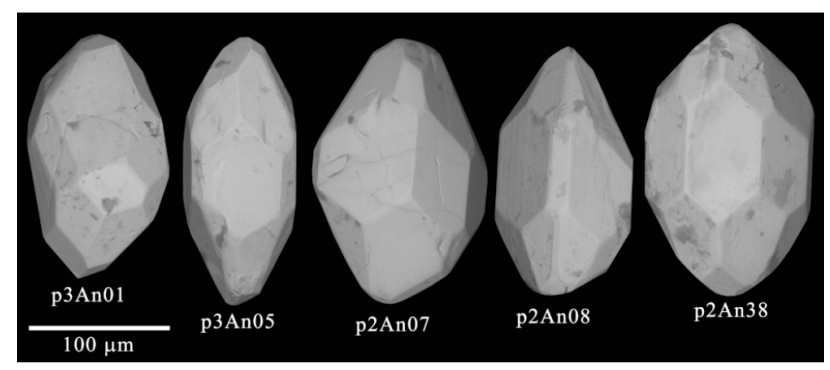

Fig. 7. Secondary electron (SE) images of selected zircon crystals from orthogneiss sample An. See text for description.
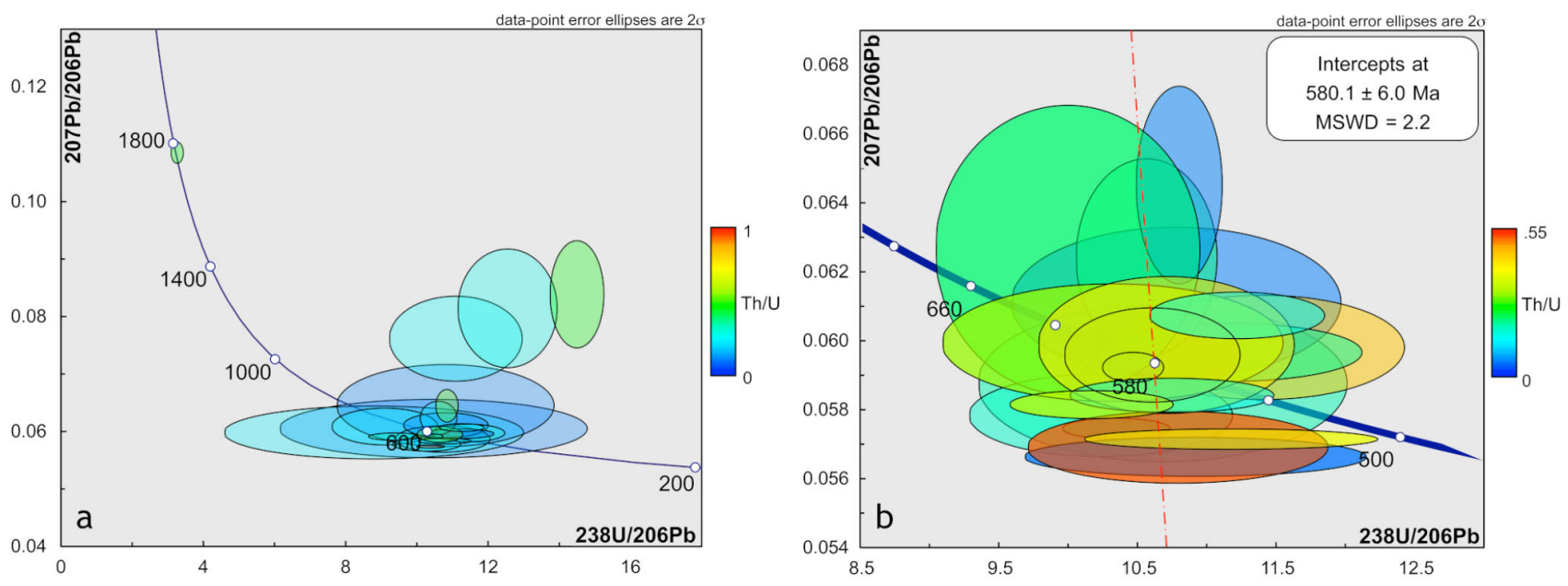

Fig. 6. Tera-Wasserburg diagrams presenting the U/Pb age of the zircons from granite sample Bu1: a) all data points; $b)$ concordant to subconcordant data points. The inherited xenocryst (p2Bu_23) and the three data points showing recent lead loss (p3Bu_01/1, p3Bu_01/1, p3Bu_09/1) are not shown. 


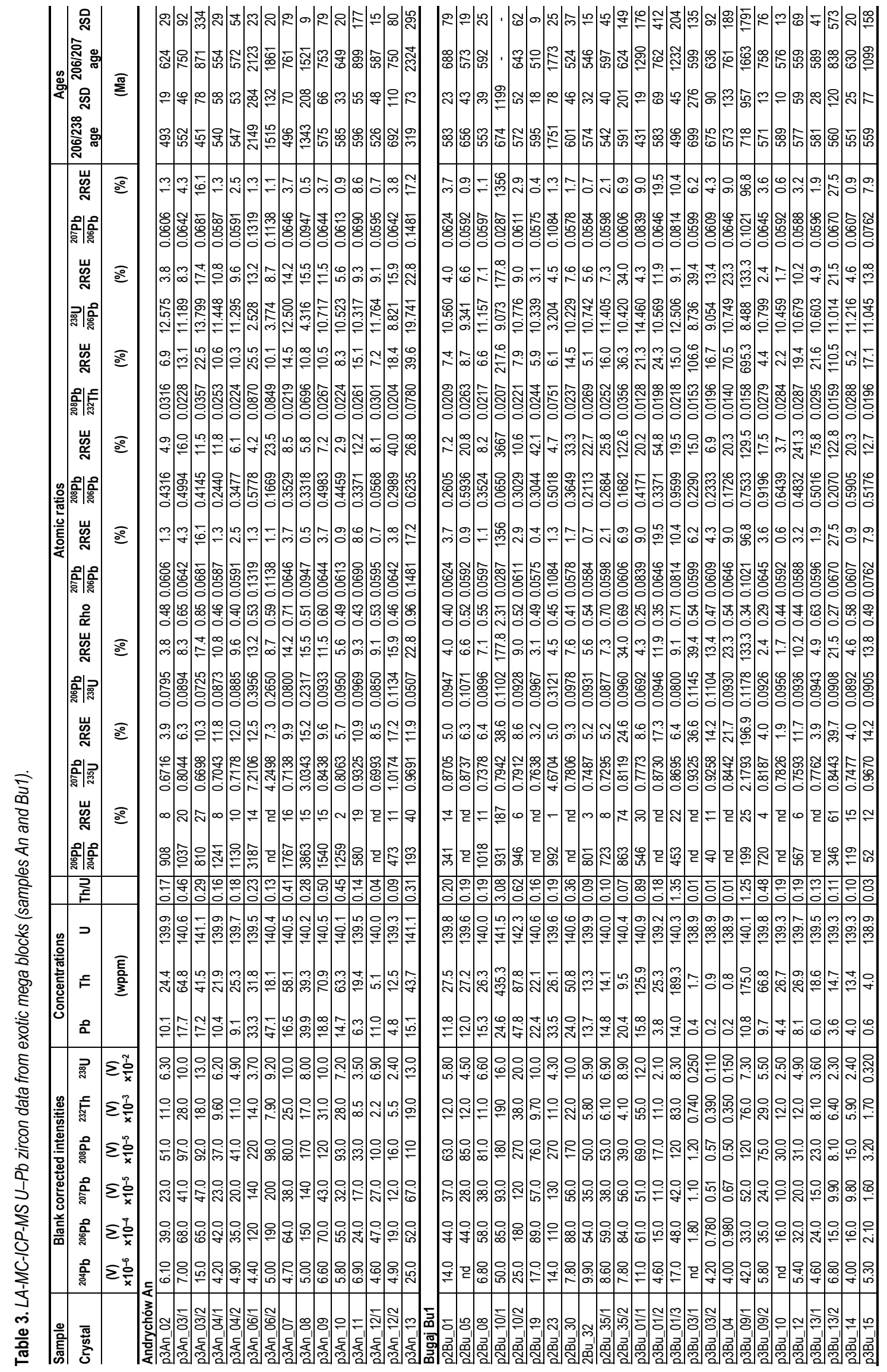




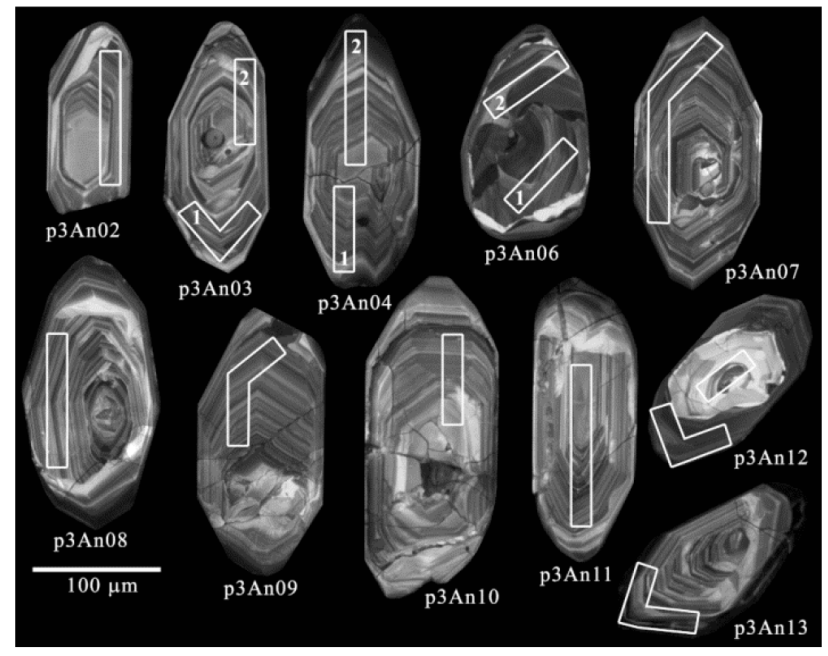

Fig. 8. Compiled cathodoluminescence (CL) images showing the range of textures observed in zircon crystals from orthogneiss sample An. See text for details. The white rectangles show the approximate location of laser ablation trenches (confirmed by re-inspecting grains under $C L$ after the $L A$ analysis) and are not to scale. The numbers refer to the analytical data presented in Table 3.

The calculated upper intercept value of $2432 \pm 1500 \mathrm{Ma}$ of i) is well within uncertainty with the concordant age value of $2123 \pm 23 \mathrm{Ma}$ used for the calculation in ii). Also the two lower intercept ages are identical within their uncertainty limits.

The remaining analyses either are strongly discordant (discordance $>10 \%$ ) or sub-concordant (discordance $<5 \%$ ) at ${ }^{207} \mathrm{~Pb} /{ }^{206} \mathrm{~Pb}$ ages between $2324 \pm 295 \mathrm{Ma}$ and $624 \pm 29 \mathrm{Ma}$. The $\mathrm{Th} / \mathrm{U}$ ratios of these analyses are identical to the former one $(0.18 \pm 0.06)$.

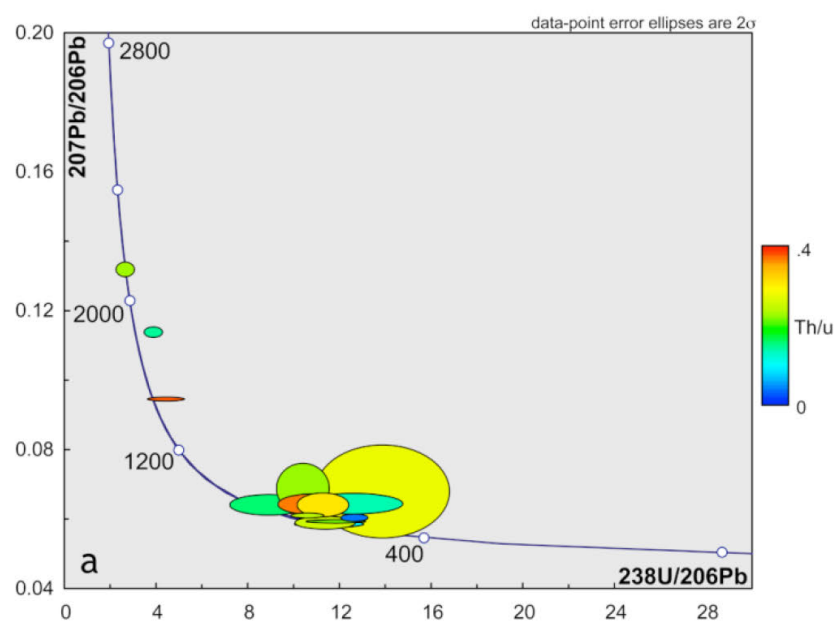

\section{DISCUSSION}

Exotics represent one of the most important sources of information about Carpathian alimentary areas, indirectly indicating their geotectonic history. For both exotic mega blocks (sample Bugaj and sample Andrychów) igneous formation ages were derived from the zircon $\mathrm{U}-\mathrm{Pb}$ data.

The Cadomian age $(580.1 \pm 6.0 \mathrm{Ma})$ from sample $B u 1$ is interpreted as magmatic crystallization age of the Bugaj granitoids. A fine-scale oscillatory zonation in the $\mathrm{CL}$ images as well as $\mathrm{Th} / \mathrm{U}$ ratio of $0.16 \pm 0.07$ point to igneous crystal growth (Corfu et al., 2003). Three analyses $(\mathrm{Th} / \mathrm{U}$ ratios $0.30 \pm 0.04)$, forming a cluster with a lower intercept age of $662 \pm 37 \mathrm{Ma}$ are interpreted to reflect a major contribution from a single inheritance source to the $c a .580 \mathrm{Ma}$ igneous event. The singular ${ }^{20} 7 \mathrm{~Pb} /{ }^{206} \mathrm{~Pb}$ age of $1773 \pm 25 \mathrm{Ma}\left(\mathrm{p} 2 \mathrm{Bu} \_23\right)$ represents a xenocryst.

The $\mathrm{Sr}$ and Nd whole-rock isotope data are controversial. The initial (at $c a .580 \mathrm{Ma}){ }^{87} \mathrm{Sr} /{ }^{86} \mathrm{Sr}$ ratios of the Bugaj granitoids (0.72997 and 0.72874) are highly radiogenic, pointing to the assimilation of an older, possibly strongly $\mathrm{Rb}$ enriched source to the Bugaj melt. On the other hand, the $\mathrm{Nd}$ isotope systematics $\left(\varepsilon_{\mathrm{Nd} 580}-1.4\right.$ and $0.4)$ rather point to a significant contribution of a distinct mantle source to the Bugaj melt. These geochemical data thus allow to recognize a hybrid geochemical character of the investigated rocks and/or decoupling of the $\mathrm{Rb}-\mathrm{Sr}$ and $\mathrm{Sm}-\mathrm{Nd}$ isotopic systems during post-magmatic alteration also supported by the presence of mafic enclaves. Such a hybrid character is also reflected in the high K-calcalkaline series affinity with the intermediate association of the ferroan and magnesian families (Frost and Frost, 2008). Also the relatively high $T h_{N} / U_{N}$ ratios (2.06 and

Fig. 9. Tera-Wasserburg diagrams for isotopic ratio for zircon crystals from orthogneiss sample An: a) all data points; b) concordant to subconcordant data points defining a discordia line with a lower intercept of $542 \pm 21$ Ma (forced through data point p3An_06/1). The inherited xenocrysts (p3An_06/1, p3An_06/2) and the two data points showing recent lead loss (p3An_08, p3An_13) are not shown. 
1.05) are remarkably well reflected in the high $\mathrm{Th} / \mathrm{U}$ ratios of some zircon domains $(0.72 \pm 0.35)$. It is not clear, whether this hybridisation is a primary one, i.e. occurring during protolith formation or a secondary one.

The biotite K-Ar age of $485 \pm 10 \mathrm{Ma}$ (Haber and Hałas, 2001) indicates either slow cooling to $c a .300^{\circ} \mathrm{C}$ after the $580 \mathrm{Ma}$ magmatic event or a Lower Ordovician thermal and possibly fluid-related overprint, which might have caused the resetting of the $\mathrm{Rb}-\mathrm{Sr}$ system which resulted in highly radiogenic ${ }^{87} \mathrm{Sr}{ }^{86} \mathrm{Sr}$ ratios. It has to be noticed however, that such an event is not detected in the $\mathrm{U}-\mathrm{Pb}$ zircon data. This fact is in favour of the slow cooling model.

In the Andrychów sample, the lower intercept age of $542 \pm 21 \mathrm{Ma}$, obtained from zircon domains exhibiting a fine-scale oscillatory growth zonation in the CL images, is interpreted as the uppermost Proterozoic to Cambrian magmatic crystallization age of the granitic precursor of the orthogneiss. The concordant age at $2123 \pm 23 \mathrm{Ma}$ represents Palaeoproterozoic inheritance. There is no evidence for a Variscan (Devonian-Carboniferous) or Alpine (Neogene) metamorphic overprint, neither from the zircon $\mathrm{U}-\mathrm{Pb}$ age systematics nor from the zircon mineral chemistry, i.e. the $\mathrm{Th} / \mathrm{U}$ ratios (samples $B u l$ and $A n$ ), and the whole-rock isotope geochemistry (sample $B u 1$ ). Lack of any Variscan overprint suggests no similarities of the analysed exotic mega blocks to the crystalline basement of the Inner Western Carpathians, showing the Variscan consolidation, e.g. from granitoids of the Tatra Massif (e.g. Burda and Klötzli, 2011; Burda et al., 2013).

The U-Pb zircon ages presented in this study are consistent with published results (monazite Th-U-total $\mathrm{Pb}$ dating, K-Ar dating of muscovite and biotite), reported from clastic material supplying Silesian basin from the Brunovistulicum and/or Małopolska Terranes as northern source areas (Poprawa et al., 2004, 2005, 2006; Budzyń et al., 2008, 2011).

The sequence of events obtained from $\mathrm{U}-\mathrm{Pb}$ zircon ages from Bugaj and Andrychów exotic mega blocks shows similarities to magmatic-metamorphic events identified in the Brunovistulicum Terrane. These events include: a) terrane collision with deformation, metamorphism and plutonism at ca. 650-620 Ma; b) arc-type granitoid intrusions at $c a$. 590-580 Ma and c) late bimodal magmatism and strike-slip deformation at $c a$. 560-550 Ma. No evidence for Variscan magmatism and/or metamorphism has emerged (e.g. Finger et al., 2000; Żelaźniewicz et al., 2009 and references therein). Also the $\varepsilon_{\mathrm{Nd} 580}$ (-1.4 and 0.4) obtained for the Bugaj granitoid is similar to the Neoproterozoic igneous rocks from the Brunovistulicum Terrane having $\varepsilon_{\mathrm{Nd} 580}$ values ranging from -1 to +3 (Finger et al., 2000).

Our investigations thus support the connection of the exotic mega blocks with the Avalonian-Cadomian orogenic belt during the Neoproterozoic (Żelaźniewicz et al., 2009).

\section{CONCLUSIONS}

1) For both exotic mega blocks (Bugaj and Andrychów) igneous formation ages could be derived from the zircon U-Pb data. These are $542 \pm 21$ Ma for the orthogneiss from Andrychów and 580.1 $\pm 6.0 \mathrm{Ma}$ for the granitoid from Bugaj.

2) The U-Pb zircon ages, derived from $>100 \mathrm{~m}$ sized exotic mega blocks, directly reflect the presence of substantial amounts of a proximal 'Cadomian' aged crust proper in the vicinity of the WOC basement. This is a marked difference to earlier published data, which are derived from $\mathrm{cm}-\mathrm{dm}$ sized pebbles only. As these can easily be derived from re-sedimented sources the ages do not necessarily reflect direct derivation from a 'Cadomian' basement, inasmuch as transport distances are not known.

3) Exotic mega blocks deposited to the WOC basins were related to the Brunovistulicum Terrane. They belong to the group of Vendian/Early Cambrian granitoids, representing the latest, post-tectonic expression of the Cadomian cycle.

\section{ACKNOWLEDGEMENTS}

We are grateful to Ewa Teper (University of Silesia in Katowice) for help with CL investigations. Monika Horschinegg (University of Vienna) is thanked for help with the $\mathrm{Rb}-\mathrm{Sr}$ and $\mathrm{Sm}-\mathrm{Nd}$ isotope determinations. Christoph Hauzenberger (Karl-Franzens University Graz) and Dorothee Hippler (Technical University Graz) kindly provided access to their joint LA-MC-ICP-MS facility. Financial means provided by the DS found of the University of Silesia in Katowice to JB and BWŚ, by the Austrian Science Fund FWF to UK (FWF M-1371-N19) and by the Polish National Science Centre (NCN) UMO2016/23/B/ST10/01896 to AG are also acknowledged. Reviews by Hans-Joachim Massonne and the anomynous referee are highly appreciated.

\section{REFERENCES}

Batchelor RA and Bowden P, 1985. Petrogenetic interpretation of granitoid rock series using multicationic parameters. Chemical Geology 48: 43-55, DOI 10.1016/0009-2541(85)90034-8.

Belka Z, Ahrendt H., Franke W and Wemmer K, 2000. The BalticaGondwana suture in central Europe: evidence from K/Ar ages of detrital muscovites. In: Franke W, Altherr R., Haak V. and Oncken O., eds., Orogenic processes: Quantification and modelling in the Variscan Belt of central Europe. Geological Society, London, Special Publications, 179: 87-102.

Bieda F, Geroch S, Koszarski L, Książkiewicz M and Żytko K, 1963. Stratigraphie des Karpates externes polonaises (Geological research in the Carpathians). Biuletyn Instytutu Geologicznego 181: 5-174.

Budzyń B, Hetherington CJ, Williams ML, Jercinovic MJ, Dumond G and Michalik M, 2008. Application of electron probe microanalysis $\mathrm{Th}-\mathrm{U}-$ total $\mathrm{Pb}$ geochronology to provenance studies of sedimentary rocks: An example from the Carpathian flysch. Chemical Geology 254: 148-163, DOI 10.1016/j.chemgeo.2008.04.015. 
Budzyń B, Dunkley DJ, Kusiak MA, Poprawa P, Malata T, Skiba M and Paszkowski M, 2011. SHRIMP U-Pb zircon chronology of the Polish Western Outer Carpathians source areas. Annales Societatis Geologorum Poloniae 81: 161-171.

Buła Z, 2000. The Lower Palaeozoic of the Upper Silesia and West Małopolska (in Polish). Prace Państwowego Instytutu Geologicznego 171: 1-63.

Buła Z, Habryn R, Jachowicz-Zdanowska M and Żaba J, 2015. The Precambrian and Lower Paleozoic of the Brunovistulicum (eastern part of the Upper Silesian Block, southern Poland) - the state of the art. Geological Quarterly 59(1): 123-134.

Burda J and Klötzli U, 2011. Pre-Variscan evolution of the Western Tatra Mountains: new insights from U-Pb zircon dating. Mineralogy and Petrology 102: 99-115, DOI 10.1007/s00710-011-0176-4.

Burda J, Gawęda A and Klötzli U, 2013. Geochronology and petrogenesis of granitoid rocks from the Goryczkowa Unit, Tatra Mountains (Central Western Carpathians). Geologica Carpathica 64(6): 419435, DOI 10.2478/geoca-2013-0029.

Burtanówna J, Konior K and Książkiewicz M, 1937. Carte géologique des Karpates de Silésie. PAU, Wydawnictwo Sląskie, Kraków, 104pp (in Polish).

Cieszkowski M, Slączka A and Wdowiarz S, 1985. New data on structure of the flysch Carpathians. Przeglad Geologiczny 33: 313-333.

Cieszkowski M, Golonka J, Krobicki M, Ślaczka A, Oszczypko N, Waśkowska A and Wendorff M, 2009. The Northern Carpathians plate tectonic evolutionary stages and origin of olistoliths and olistostromes. Geodynamica Acta 22(1-2): 1-26.

Cieszkowski M, Golonka J, Ślączka A and Waśkowska A, 2012. Role of the olistostromes and olistoliths in tectonostratigraphic evolution of the Silesian Basin in the Outer West Carpathians. Tectonophysics 568-569: 248-265, DOI 10.1016/j.tecto.2012.01.030.

Corfu F, Hanchar JM, Hoskin PWO and Kinny PD, 2003. Atlas of zircon textures. Reviews in Mineralogy and Geochemistry 53: 469-500, DOI 10.2113/0530469.

De la Roche H, Leterrier J, Grandclaude P and Marchal M, 1980. A classification of volcanic and plutonic rocks using R1, R2diagrams and major element analysis - its relationships with current nomenclature. Chemical Geology 29:183-210, DOI 10.1016/0009-2541(80)90020-0.

Dudek A, 1980. The crystalline basement block of the Outer Carpathians in Moravia: Bruno-Vistulicum. Rozpravy Česko-Slovenské Akademie Věd, Řada Matematicko-přirodnich Věd 90: 1-85.

Finger F, Hanžl P, Pin C, Quadt A and Steyrer HP, 2000. The Brunovistulicum: Avalonian Precambrian at the eastern end of the Variscides. In: Franke W, Altherr R, Haak W, Oncken O and Tanner D., eds., Orogenic Processes: Quantification and Modelling in the Variscan Belt of Central Europe. Geological Society of London, Special Publication 179: 103-112.

Frost BR and Frost CD, 2008. A Geochemical Classification for Feldspathic Igneous Rocks Journal of Petrology 49: 1955-1969, DOI 10.1093/petrology/egn054.

Golonka J, Aleksandrowski P, Aubrecht M, Chowaniec J, Chrustek M, Cieszkowski M, Florek R, Gawęda A, Jarosiński M, Kępińska B, Krobicki M, Lefeld J, Lewandowski M, Marko F, Michalik M, Oszczypko N, Picha F, Potfaj M, Słaby E, Ślączka A, Stefaniuk M, Uchman A and Żelaźniewicz A, 2005. Orava Deep Drilling Project and the Post Paleogene tectonics of the Carpathians. Annales Societatis Geologorum Poloniae 75: 211-248.

Golonka J, Krobicki M, Waśkowska-Oliwa A, Vašiček Z and Skupien $\mathrm{P}, 2008$. Główne elementy paleogeograficzne Karpat Zewnętrznych w późnej jurze i wczesnej kredzie (Main palaeogeographical elements of West Outer Carpathians during Late Jurassic and Early Crataceous times). Geologia 34(3): 61-72.

Golonka J, Pietsch K, Marzec P, Stefaniuk M, Waśkowska A and Cieszkowski M, 2009. Tectonics of the western part of the Polish Outer Carpathians. Geodynamica Acta 22(1-2): 81-97.

Haber M and Hałas S, 2001. Granit z Bugaja ma 485 milionów lat. (Granite from Bugaj is 485 million years old (southern Poland). Przeglad Geologiczny 49(7): 613-615 (in Polish).

Hanžl $\mathrm{P}$, Schnitter F, Finger $\mathrm{F}$, Krejči $\mathrm{O}$, Buriankovà $\mathrm{K}$ and Strànik, Z, 2000. Petrography, geochemistry and age of granitic pebbles from the Moravian part of the Carpathian Flysch. Polskie Towarzystwo Mineralogiczne - Prace Specjalne 17: 156-158.

Klötzli U, Klötzli E, Günes Z and Košler J, 2009. External accuracy of laser ablation $\mathrm{U}-\mathrm{Pb}$ zircon dating: results from a test using five different reference zircons. Geostandards and Geoanalytical Research 33(1): 5-15.

Košler J, Forst L and Sláma J, 2008. Lamdate and Lamtool: spreadsheet-based data reduction for laser ablation ICP-MS. In: Sylvester P, ed., Laser Ablation ICP-MS in the Earth sciences: Current Practices and Outstanding Issues. Mineralogical Association of Cana$d a$, Short Course 40: 315-317.

Książkiewicz M, 1953. Flysh Carpathians beetwen the Olza and Dunajec rivers. In: Regional geology of Poland, vol. 1: Carpathians. Part 1: Tectonics. Tome 2: Carpathians. PTG, Kraków: 305-361 (in Polish).

Książkiewicz M, 1960. Pre-orogenic sedimentation in the Carpathian geosyncline. Geologische Rundschau 50: 8-31

Książkiewicz M (ed.), 1962. Geological Atlas of Poland. Stratigraphic and facial problems Fasc. 13 - Cretaceous and Tertiary in the Polish External Carpathians, 1:600 000. Państwowy Instytut Geologiczny, Warszawa.

Książkiewicz M, 1965. Les cordillàres dans les mers Crétacées et Paléogànes des Carpates du Nord. Bulletin de la Societé Géologique de France 7: 443-455 (in French).

Książkiewicz M, 1972. Budowa geologiczna Polski, t. IV, Tektonika, cz. 3. Karpaty. (Geology of Poland, vol.4 Tectonics, part 3 Carpathians).Wydawnictwa Geologiczne, Warszawa: 228 pp. (in Polish).

Książkiewicz M, 1977. The Tectonics of the Carpathians. In: Geology of Poland, vol. 4.Tectonics. The Alpine Tectonic Epoch. Geological Institute, Warsaw: 476-608.

Ludwig KR, 2012. User's Manual for Isoplot Version 3.75-4.15: A Geochronological Toolkit for Microsoft Excel. 5. Berkley Geochronological Centre, Special Publication.

Malik K, 1978. Wstępne wyniki badań nad wapieniami egzotykowymi z warstw grodziskich (Preliminary results of studies on exotic limestones from the Grodzisko beds). Przeglad Geologiczny 26 (3): 183-184 (in Polish).

Michalik M, Budzyń B and Gehrels G, 2006. Cadomian granitoid clasts derived from the Silesian Ridge (results of the study of gneiss pebbles from Gródek at the Jezioro Rożnowskie Lake). Mineralogia Polonica - Special Papers 29: 168-171.

Middlemost EAK, 1985. Magmas and magmatic rocks. An introduction to igneous petrology. Longman Group Ltd., London, New York.

Nawrocki J, Boguckij A and Katinas V, 2004. New Late Vendian palaeogeography of Baltica and the TESZ. Geological Quarterly 48(4): 309-316.

Olszewska B and Wieczorek J, 2001. Jurassic sediments and microfossils of the Andrychów Klippes (Outer Western Carpathians). Geologia Carpathica 52/4: 217-228.

Oszczypko N, 1975. Exotic rocks in the Palaeogene of the Magura nappe between the Dunajec and Poprad Rivers (Carpathians, Poland). Annales de la Société Géologique de Pologne 45(3-4): 403431 (in Polish).

Oszczypko N, 1998. The Western Carpathian Foredeep - Development of the foreland basin in front of the accretionary wedge and its burial history (Poland). Geologica Carpathica 49: 1-18.

Oszczypko N, 2004. The structural position and tectonosedimentary evolution of the Polish Outer Carpathians. Przeglad Geologiczny 52: 780-791.

Oszczypko N, 2006. Powstanie i rozwój polskiej części zapadliska przedkarpackiego (Development of the Polish sector of the Carpathian Foredeep). Przeglad Geologiczny 54(5): 396-403.

Oszczypko N and Slączka A, 1985. An attempt to palinspastic reconstruction of Neogene basins of the Carpathian Foredeep. Annales Societatis Geologorum Poloniae 55(1-2): 55-75.

Oszczypko N and Oszczypko-Clowes M, 2003. The Aquitanian marine deposits in the basement of the Polish Western Carpathians and its paleogeographical and paleotectonic implications. Acta Geologica Polonica 53(2): 1-22. 
Oszczypko N, Oszczypko-Clowes M and Salata D, 2006. Egzotyki strefy krynickiej (płaszczowina magurska) magurska ich znaczenie paleogeograficzne (Exotic rocks of the Krynica Zone (Magura nappe) and their palaeogeographic significance). Geologia 32(1): 21-45 (in Polish).

Oszczypko N, Salata D, Konečny P, 2016. Age and provenance of mica-schist pebbles from the Eocene conglomerates of the Tylicz and Krynica Zone (Magura Nappe, Outer Flysch Carpathians). Geologia Carpathica 67: 260-274.

Poprawa P, Malata T and Oszczypko N, 2002. Ewolucja tektoniczna basenów sedymentacyjnych polskiej części Karpat zewnętrznych w świetle analizy subsydencji (Tectonic evolution of the Polish part of Outer Carpathian's sedimentary basins - constraints from subsidence analysis). Przeglad Geologiczny 50: 1092-1108 (in Polish).

Poprawa P, Malata T, Pécskay Z, Banaś M, Skulich J, Paszkowski M and Kusiak MA, 2004. Geochronology of crystalline basement of the Western Outer Carpathians' sediment source areas. Polskie Towarzystwo Mineralogiczne - Prace Specjalne 24: 329-332.

Poprawa P, Kusiak MA, Malata T, Paszkowski M, Pécskay Z and Skulich, J, 2005. Th-U-Pb chemical dating of monazite and K/Ar dating of mica combined: preliminary study of "exotic" crystalline clasts from the Western Outer Carpathian flysch (Poland). Polskie Towarzystwo Mineralogiczne - Prace Specjalne 25: 345-351.

Poprawa P, Malata T, Pécskay Z, Kusiak MA, Banaś M and Paszkowski M, 2006. Geochronology of the crystalline basement of the Western Outer Carpathians' source areas - constraints from the K/Ar dating of mica and $\mathrm{Th}-\mathrm{U}-\mathrm{Pb}$ chemical dating of monazite from the crystalline 'exotic' pebbles. Geolines 20: 110-112.

Poprawa P and Malata T, 2006. Model of Late Jurassic to Early Miocene tectonic evolution of the Western Outer Carpathians. Przeglad Geologiczny 54: 1066-1080 (in Polish).

Pupin JP, 1980. Zircon and Granite Petrology. Contributions to Mineralogy and Petrology 73: 207-220, DOI 10.1007/BF00381441.

Salata D and Oszczypko N, 2010. Preliminary results of provenance analyses of exotic magmatic and metamorphic rock pebbles from the Eocene flysch deposits of the Magura Nappe (Krynica facies zone, Polish Outer Carpathians). In: Christofidis G, Kantiranis N, Kostopoulos DN and Chatzipetros AA, eds., Proceedings of the XIX CBGA Congress, Thessaloniki, Greece. Scientific Annals, School of Geology, Aristotle University of Thessaloniki, special volume 100: 241-249.

Sikora WJ, 1976. Kordyliery Karpat Zachodnich w świetle tektoniki płyt litosfery (Cordilleres of the Western Carpathians in the light of the plate tectonics theory). Przeglad Geologiczny 6: 336-349 (in Polish).

Sláma J, Košler J, Condon DJ, Crowley JL, Gerdes A, Hanchar JM., Horstwood MSW, Morris GA, Nasdala L, Norberg N, Schaltegger U, Schoene B, Tubrett MN and Whitehouse MJ, 2008. Plešovice zircon - a new natural reference material for $\mathrm{U}-\mathrm{Pb}$ and $\mathrm{Hf}$ isotopic microanalysis. Chemical Geology 249: 1-35, DOI 10.1016/j.chemgeo.2007.11.005.

Ślączka A, 1986. Europejskie spotkania sedymentologów (European sedimentologists' meetings). Przeglad Geologiczny 34(4): 231.

Ślączka A and Kaminski MA, 1998. A Guidebook to Excursions in the
Polish Flysch Carpathians. Grzybowski Foundation Special Publication 6: $171 \mathrm{pp}$

Ślączka A, Krugłov S, Golonka J, Oszczypko N and Popadyuk I, 2006. Geology and Hydrocarbon Resources of the Outer Carpathians, Poland, Slovakia, and Ukraine: General Geology. In: Golonka J and Picha FJ, eds., The Carpathians and their foreland: Geology and hydrocarbon resources. AAPG Memoir 84: 221-259.

Sun SS and McDonough WF, 1989. Chemical and isotopical systematics of oceanic basalts: implications for mantle composition and processes. Magmatism in the Oceanic Basins. Geological Society of London Special Pubplications 42: 313-345.

Sylvester PJ and Ghaderi M, 1997. Trace element analysis of scheelite by excimer laser ablation-inductively coupled plasma-mass spectrometry (ELA-ICP-MS) using a synthetic silicate glass standard. Chemical Geology 141: 49-65, DOI 10.1016/S00092541(97)00057-0.

Thöni M, Miller C, Zanetti A, Habler G and Goessler W, 2008. Sm-Nd isotope systematics of high-REE accessory minerals and major phases: ID-TIMS, LA-ICPMS and EPMA data constrain multiple Permian-Triassic pegmatite emplacement in the Koralpe, Eastern Alps. Chemical Geology 254: 216-237, DOI 10.1016/j.chemgeo.2008.03.008.

Unrug R, 1963. Istebna beds - a fluxoturbidity formation in the Carpathian Flysch. Rocznik Polskiego Towarzystwa Geologicznego 33: 49-92.

Unrug R, 1968. Kordyliera ślaska jako obszar źródłowy materiału klastycznego piaskowców fliszowych Beskidu Śląskiego i Beskidu Wysokiego (Polskie Karpaty zachodnie) (The Silesian cordillera as the source of clastic material of the Flysch sandstones of the Beskid Śląski and Beskid Wysoki ranges (Polish Western Carpathians). Rocznik Polskiego Towarzystwa Geologicznego 38: 81164.

Watson TM and Harrison EB, 1983. Zircon saturation revisited: temperature and composition effects in a variety of crustal magma types. Earth and Planetary Science Letters 64: 295-304, DOI 10.1016/0012-821X(83)90211-X.

Wieser T, 1948. Crystalline exotic blocks in the Silesian Cretaceous of the Wadowice area (Pl. I-II). Annales Societatis Geologorum Poloniae 18: 36-150 (in Polish).

Wieser T, 1949. Egzotyki krystaliczne w kredzie ślaskiej okolic Wadowic (Crystalline exotic blocks in the Silesian Cretaceous of the Wadowice area). Rocznik Polskiego Towarzystwa Geologicznego 18: 36-105 (in Polish).

Wieser T, 1985. Some remarks on the sedimentation, composition and provenance of exotic bearing conglomerates in the western Polish Carpathians Flysch formations. $13^{\text {th }}$ Congress Carpatho-Balkan Geological Association, Guide 1. Geological Institute, Kraków: $57-68$.

Żelaźniewicz A, Buła Z, Fanning M, Seghedi A and Żaba J, 2009. More evidence on Neoproterozoic terranes in Southern Poland and south eastern Romania. Geological Quarterly 58(1): 93-124.

Żelaźniewicz A, Aleksandrowski P, Buła Z, Karnkowski PH, Konon A, Oszczypko N, Ślączka A, Żaba J and Żytko K, 2011. Regionalizacja tektoniczna Polski (Tectonic regionalization of Poland). Komitet Nauk Geologicznych PAN, Wrocław: 59 pp (in Polish). 